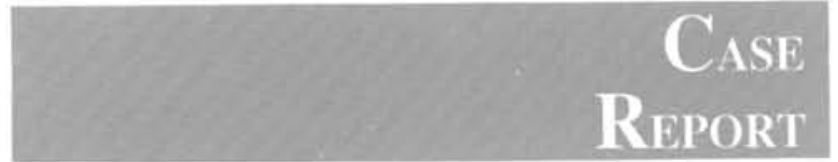

Marcos Yorghi Khoury, Edmund Chada Baracat, Dolores Perovano Pardini, Mauro Abi Haidar,

\title{
Polycystic ovary syndrome: Clinical and laboratory evaluation
}

\author{
Department of Gynecology, Escola Paulista de Medicina, Universidade Federal de São Paulo - São Paulo, Brazil
}

\begin{abstract}
Objective: To evaluate clinically, and with laboratory, tests, women with polycystic ovary syndrome (PCO). Patients: One hundred and twelve women with PCO were studied. Methods: The following data was recorded: Current age; age at menarche; menstrual irregularity, occurrence of similar cases in the family; fertility, obstetric history; body mass index (BMI); and presence of hirsutism. Serum measurements of follicle stimulating hormone (FSH), luteinizing hormone (LH), prolactin, free testosterone, and dehydroepiandrosterone sulfate were taken. Results: All patients presented either oligomenorrhea ( 31 percent), periods of secondary amenorrhea (9 percent), or both alterations ( 60 percent). The majority of the patients were infertile (75.6 percent). The LH/FSH ratio was higher than 2:1 in 55 percent of the patients and higher than 3:1 in 26.2 percent. The ultrasonographic aspect of the ovaries was considered to be normal in 31 percent. Conclusion: The main clinical feature of the PCO is the irregularity of menses since menarche, and that the laboratory tests would be important to exclude other disorders such as hyperprolactinemia or hyperandrogenemia caused by late-onset congenital adrenal hyperplasia.
\end{abstract}

UNITERMS: Polycystic Ovary syndrome. Oligomenorrhea. Secondary amenorrhea.

\section{INTRODUCTION}

Polycystic ovary syndrome (PCO) was first described by Stein and Leventhal in 1935 in women presenting oligomenorrhea, hirsutism, obesity, and enlarged polycystic ovaries. ${ }^{1}$ However, some of these characteristics may not be present in the syndrome.

Many theories have been advanced to explain the physiopathology of $\mathrm{PCO},{ }^{2-4}$ but its etiology continues to elude gynecologists and endocrinologists. ${ }^{3}$ In the present

\author{
Adress for correspondence: \\ Marcos Yorghi Khoury \\ Escola Paulista de Medicina \\ Rua Napoleão de Barros, 715 - $7^{\circ}$ andar - Vila Clementino \\ São Paulo/SP - Brasil - CEP 04024-002
}

study we evaluated the clinical characteristics and laboratory findings most frequently detected in the syndrome.

\section{MATERIAL AND METHODS}

A retrospective study was conducted on 112 women with PCO followed up at the Division of Gynecological Endocrinology, Department of Gynecology, Escola Paulista de Medicina, Universidade Federal de São Paulo. All patients were submitted to detailed clinical and gynecological examinations supplemented with plasma hormone measurements. and pelvic ultrasound (PUS). Current age, age at menarche, menstrual irregularity, 
occurrence of similar cases in the family, fertility, obstetric history, body mass index (BMI), and presence or absence of hirsutism were recorded. The last parameter was evaluated by the index of Ferriman and Gallwey (IFG). ${ }^{5}$ Women were considered to be hirsute when their IFG was 6 or above.

Serum measurements of follicle stimulating hormone (FSH), ${ }_{6}^{6}$ luteinizing hormone $(\mathrm{LH}),{ }^{6}$ prolactin $(\mathrm{PRL}),{ }^{7}$ free testosterone (free T), ${ }^{8}$ and dehydroepiandrosterone sulfate (DHEAS), ${ }^{9}$ were performed by radioimmunoassay.

\section{RESULTS}

The age of the patients ranged from 16 to 32 years (mean \pm standard deviation [SD] 22.3 \pm 4.0 ). The age at menarche was from 9 to 18 years (mean $13.3 \pm 2.0$ ). The age of onset of menstrual irregularity was from 10 to 24 (mean 13.9 \pm 2.5 ). Menstrual alteration had occurred since menarche in 84 percent of the cases.

Figure 1 illustrates the menstrual pattern of the patients. All of them presented either oligomenorrhea, periods of secondary amenorrhea, or both alterations. Similar cases in their families were reported by 25.7 percent of the patients. It is interesting to note that 5.3 percent of the women reported that their mothers presented the same clinical picture.

A large majority of the women had never been pregnant (90.2 percent). Only 7.1 percent had had one pregnancy, and the other 2.7 percent had had two or more pregnancies. Infertility was present in 75.6 percent of the women.

The mean BMI value was $23.84 \pm 5.25$. Obesity (BMI >25) was observed in 29.4 percent of patients, and hirsutism (IFG $\geq 6$ ) in 17.9 percent.



Figure 1 - Menstrual pattern of the patients.

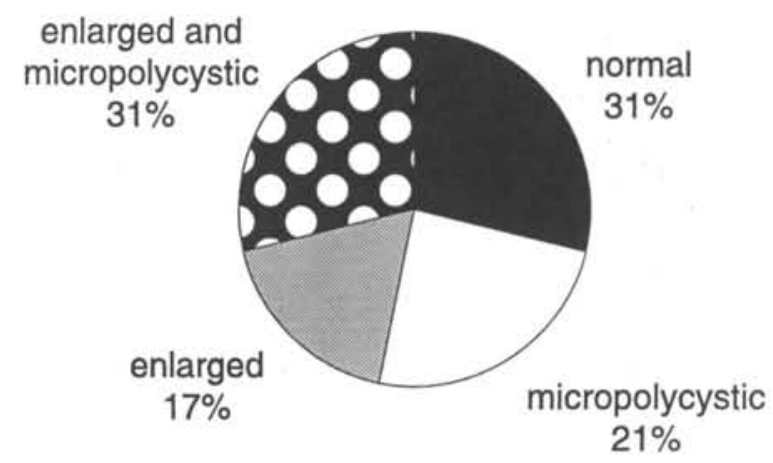

Figure 2 - Ultrasonographic aspect of the ovaries.

Mean $( \pm$ SD) serum values of $\mathrm{LH}, \mathrm{FSH}, \mathrm{PRL}$, free T, DHEAS, and of the LH/FSH ratio are shown in Table 1. It can be seen that the LH/FSH ratio was $\geq 3: 1$ in 26.2 percent of patients, and $\geq 2: 1$ in 55.0 percent. Only 14.9 percent of the patients had hyperprolactinemia (PRL $\geq 20 \mathrm{ng} / \mathrm{ml}$ ).

Figure 2 shows the ultrasonographic aspect of the ovaries, considered normal in 31.0 percent of the patients.

\section{DISCUSSION}

It is generally accepted that PCO may start early in the reproductive life of women, perhaps even before menarche. ${ }^{10}$ The theory of adrenarche suggests that the reticular zone of the adrenal may be inappropriately stimulated, causing an increase in androgen levels, which in turn may lead to an increased extraglandular estrogen production. ${ }^{4}$

Other investigators, however, consider the central nervous system to be the initial causal factor of PCO. ${ }^{2}$ In this case, a decrease in hypothalamic opiods and dopaminergic tonus may lead to an increase in pulsatile gonadotropin releasing hormone $(\mathrm{GnRH})$ secretion by the hypothalamus, with a consequent alteration in gonadotropin secretion. Inappropriate gonadotropin secretion with an increased LH/FSH ratio may lead to hyperandrogenemia, micropolycystic ovaries and increased peripheral conversion of androgens to estrogens, especially of androstenedione to estrone. High estrone levels and normal estradiol levels may promote inappropriate gonadotropin secretion by increasing the sensitivity of pituitary $\mathrm{LH}$ to $\mathrm{GnRH}$, with the consequent occurrence of a vicious cycle. ${ }^{2}, 11$

The major characteristic of PCO is chronic anovulation, which in our series was reflected by oligomenorrhea and/or secondary amenorrhea. This 
Table 1

Mean (SD) serum values of LH (U/L) FSH (U/L) PRL ( $\mathrm{ng} / \mathrm{mL}$ ) LH/FSH ratio free $\mathrm{T}(\mathrm{pg} / \mathrm{mL})$ and DHEAS $(\mu \mathrm{g} / \mathrm{dL})$

\begin{tabular}{llllll}
\hline LH $^{*}$ & FSH & LH/FSH & PRL $\neq$ & T livre§ & DHEASII \\
\hline $23.9 \pm 14.7$ & $12.2 \pm 6.9$ & $2.3 \pm 1.3$ & $14.0 \pm 8.2$ & $2.4 \pm 0.9$ & $186 \pm 84$ \\
\hline
\end{tabular}

* Normal values in women during follicular phase range from 1.5 to $10.0 \mathrm{U} / \mathrm{L}$. † Normal values in women during follicular phase range from 2.9 to $12.0 \mathrm{U} / \mathrm{L}$. $\ddagger$ Normal values in women are up $20 \mathrm{ng} / \mathrm{ml}$.

$\S$ Normal values in women range from 0.2 to $3.2 \mathrm{pg} / \mathrm{ml}$.

II Normal values in women range from 50 to $340(\mu \mathrm{g} / \mathrm{dl})$.

chronic anovulation also explains the high incidence of infertility detected here.

Several studies have shown a higher prevalence of the syndrome up to 25 years of age. In our series, the women were also young, with 80 percent of them being less than 25 years old, and presenting irregular menses that started soon after menarche.

Obesity has been associated with PCO since the syndrome was first described,' and was present in 29.7 percent of our patients. These data coincide with those reported in the literature, which reveals an incidence of 30 to 50 percent. ${ }^{12}$ The role of obesity in the genesis of the syndrome is still unclear. However, it has been demonstrated that in some women with $\mathrm{PCO}$, weight loss reduces estrone levels, gonadotropin secretion, and normalizes the menses. ${ }^{3}$

It has been reported that 50 to 70 percent of patients with PCO have hirsutism. ${ }^{12,13}$ Only 18 percent of our patients had hirsutism, and the phenomenon was mild in most of them $(\mathrm{IFG}<8)$. This result, which disagrees with the literature, shows that the prevalence of hirsutism was not relevant in our sample, and was only slightly higher than in the general population. ${ }^{14}$

It is interesting that 25.7 percent of our patients reported a similar case in their family, a fact perhaps suggesting a genetic alteration, although this cannot be proved.

We detected an LH/FSH ratio higher than 2 in 55 percent of the patients, and higher than 3 in 26.2 percent. These data show that inappropriate $\mathrm{LH}$ secretion in $\mathrm{PCO}^{2}$ is not necessarily accompanied by an increase in plasma LH/FSH ratio.

The association of hyperprolactinemia with PCO was noted a long time ago. Some investigators, however, consider it to be a random occurrence because of the relative frequency of the two disorders. ${ }^{15}{ }^{16}$ Others, however, believe that both conditions may be related to an increase in LH/ FSH ratio and to a decrease in dopaminergic tonus. ${ }^{17}$ Hyperprolactinemia is estimated to occur in approximately 25 percent of women with $\mathrm{PCO} .{ }^{18}$ Our findings differ considerably from those reported in the literature, since we detected this association in only 14.9 percent of the patients. This discrepancy may perhaps be explained by the different methodologies adopted to measure plasma prolactin. In our opinion, however, the determination of this hormone is still imperative in all women with PCO.

Androgen production is increased in patients with PCO compared to normal women, with plasma testosterone levels being elevated in only 50 percent of these patients. This discrepancy is explained in part by the reduced binding ability of sex hormone binding globulin (SHBG), and the consequent increase in the metabolic rate of testosterone clearance, since there is more free $\mathrm{T}$ in plasma. ${ }^{19}$ Surprisingly, we did not detect high levels of free T or DHEAS in our cases. Several studies have shown that plasma androgen levels are usually normal, even in hirsute women..$^{20}$

In 69 percent of our patients; we detected an increased ovarian volume and/or the presence of micropolycysts inside the ovaries by PUS. This means that 31 percent of the patients had normal ovaries when examined by PUS. These data suggest that the presence of enlarged and micropolycystic ovaries is frequently detected by PUS, but that their absence does not exclude the diagnosis of PCO. Ultrasonography is particularly useful in borderline cases with suggestive clinical histories, which do not present, for example, changes in the LH/FSH ratio. ${ }^{21}$

On the basis of our results, we may conclude that the clinical history continues to be the major weapon for the diagnosis of PCO. The most important clinical finding is the irregularity of menses, since menarche is characterized by oligomenorrhea and/or secondary amenorrhea. Auxiliary tests such as the determination of the LH/FSH ratio would be important to confirm the diagnosis, or to exclude other disorders (such as hyperprolactinemia or hyperandrogenemia) caused by enzymatic defects of the adrenal glands, or by functioning ovarian or adrenal tumors. 


\section{RESUMO}

Objetivos: Avaliar clinica e laboratorialmente mulheres com a sindrome dos ovários policisticos (SOP). Pacientes: Foram estudadas 112 mulheres com SOP. Métodos: Avaliamos idade, idade da menarca, história menstrual, época do aparecimento da irregularidade menstrual, ocorrência de casos semelhantes na familia, antecedentes obstétricos, indice de massa corpórea, e presença de hirrsutismo. Foram realizadas as dosagens séricas de hormônio foliculo-estimulante (FSH), hormônio luteinizante (LH), prolactina, testosterona livre e de sulfato de dehidroepiandrosterona. Resultados: Todas as mulheres apresentavam espaniomenorréia ( 31 percent), periodos de amenorréia secundária ( 9 percent) ou ambas alteraçōes ( 60 percent). A maioria era infértil ( 75,6 percent). A relaçāo LH/FSH era maior que 3 em 26,2 percent e maior que 2 em 55,0 percent das mulheres. 0 aspecto ultra-sonográfico dos ovários era normal em 31 percent das mulheres. Conclứsão: A principal caracteristica clinica da SOP é a irregularidade menstrual desde a menarca e os exames de laboratório seriam importantes para afastar outras patologias como as sindromes hiperprolactinêmicas ou as deficiências enzimáticas tardias da supra-renal.

\section{REFERENCES}

1. Stein IF, Leventhal M. Amenorrhea associated with bilateral polycystic ovaries. Am J Obstet Gynecol 1935;29:181-91.

2. Hutchinson-Williams KA, DeCherney AH Pathogenesis and treatment of ovary disease. Int J Fertil 1987;32:421-30.

3. Speroff L, Glass RH, Kase NG. In: Clinical Gynecology and Infertility $4^{\text {th }}$ ed..Baltimore: Williams \& Wilkins. 1989;21331.

4. Yen SSC. Anovulaçāo crônica causada por distúrbios endócrinos periféricos. In: Yen SSC, Jaffe B, eds. Endocrinologia reprodutiva: fisiologia fisiopatologia e tratamento clínico. São Paulo: Roca, 1990:423-69.

5. Ferriman D, Gallwey JD. Clinical assessment of body hair growth in women. J Clin Endocrinol Metab 1961;21:1440-8.

6. Bangham DR, Berryman 1 , Burger $\mathrm{H}$, et al. An international collaborative study of $69 / 104$ a reference preparation of pituitary FSH and LH. J Clin Endocrinol Metab 1973;36:647-60.

7. Vieira JGH, Russo EMK, Lengyel AM, Maciel RMB. Desenvolvimento de um radioimunoensaio heterólogo para a dosagem de prolactina humana no soro. Arq Bras Endocrinol Metab 1981;25:107-12.

8. Jung-Hoffmann C, Taubert D, Kuhl H. Direct radioimmunoassay of free testosterone in the evaluation of androgenetic manifestation in women. Gynecol Endocrinol 1987:1:83-92.

9. Vieira JGH, Furlanetto RP, Russo EMK, Noguti KO, Chacra AR. Radioimunoensaio do sulfato de dehidroepiandrosterona: metodologia e padronização de valores normais. Arq Bras Endocrinol Metab 1980;24:79-93.
10. Lobo RA. The role of the adrenal in polycystic ovary syndrome. Semin Reprod Endocrinol 1984;2:251-262.

11. Futterweit W, Mechanick JI. Polycystic ovarian disease: Etiology diagnosis and treatment. Compr Ther 1988:14:12-20.

12. Goldzieher JW, Green JA. The polycystic ovary: I. clinical and histologic features. J Clin Endocrinol Metab 1962;22:325-38.

13. Adams J, Polson DW, Franks S. The prevalence of polycystic ovaries in women with anovulation and idiopathic hirsutism. Br Med J 1986; 293:355-8.

14. McKnight E. The prevalence of "hirsutism" in young women. Lancet 1964;1:410-3.

15. Corenblum B, Taylor PJ. The hyperprolactinemic polycystic ovary syndrome may not be a distinct entity. Fertil Steril 1982;38:549-52.

16. Seppälä M, Hirvonen E. Raised serum prolactin levels associated with hirsutism and amenorrhoea. Br Med J 1975;4:144-5.

17. Del Pozo ES, Falashi P. Prolactin and cyclicity in polycystic ovary syndrome: The role of estrogens and the dopaminergic system. Prog Reprod Biol 1980;6:252-9.

18. Futterweit W. Hyperprolactinemia and polycystic ovarian disease. In: Futterweit W. Polycystic ovarian disease. New York: Springer-Verlag, 1984; 97-111.

19. Yen SSC. The polycystic ovary syndrome. Clin Endocrinol 1980;12:177-208.

20. De Sá MFS, De Medeiros SF, De Moura MD, Ferrari RA. Ausência de correlação entre o grau de hirsutismo nos níveis de androgênios circulantes. J Bras Ginec 1988;98:45-8.

21. Hámori M, Urbancse J, Szendei G, Német J. The role of ultrasonography in treating polycystic ovary syndrome. Act Chir Hung 1988;29:27-34. 